\title{
Influence of Planting Papaya Ringspot Virus Resistant Transgenic Papaya on Soil Microbial Biodiversity
}

\author{
Yi-Ting Hsieh AND TzU-Ming Pan*
}

Institute of Microbiology and Biochemistry, National Taiwan University, Taipei, Taiwan

\begin{abstract}
To investigate the influence of papaya ringspot virus resistant transgenic papaya on soil microorganisms, upper $(0-15 \mathrm{~cm})$ and lower layers $(15-30 \mathrm{~cm})$ of soil samples were collected around transgenic papaya planting area and nontransgenic papaya planting area and from soils in which plants had not been grown. The moisture content, $\mathrm{pH}$ value, total organic carbon content, and total nitrogen content were not significantly different among groups. The populations of total count, fungi, and actinomycete were highest in upper layer soils around transgenic papaya planting area and lowest in lower layer soils in which platns had not been grown. The microbial populations were all higher in upper layer of soils. Amplified fragment length polymorphism, amplified ribosomal DNA restriction analysis, terminal restriction fragment length polymorphism, and denaturing gradient gel electrophoresis analyses indicated that the similarity of soil microorganisms of upper layer soils around transgenic papaya planting area and around nontransgenic papaya planting area was $>80 \%$. A similar result was observed in lower layer soils. Thus, planting transgenic papayas does have a limited impact on soil microorganisms.
\end{abstract}

KEYWORDS: Papaya; papaya ringspot virus (PRSV); amplified ribosomal DNA restriction analysis (ARDRA); terminal restriction fragment length polymorphism (T-RFLP); denaturing gradient gel electrophoresis (DGGE)

\section{INTRODUCTION}

The cultivation of genetically modified organisms (GMOs) has increased over the past decade. The continuing rapid adoption of GMOs reflects the substantial improvements in productivity, the environment, economics, and social benefits realized in countries ( 1 ). Although there is no clear evidence, it has been suggested that GMOs may create risks for human health and the environment such as the possibility of toxic or allergic effects, disturbance of the ecosystem, and horizontal gene transfer (2), all of which may emerge as long-term effects. GMOs may cause the possibility of the transfer of genetic information into indigenous microorganisms and unusual and potentially deleterious characters on these organisms that may perturb the natural ecosystem (3).

Papayas not only offer a luscious taste but are rich in vitamin $\mathrm{C}$ and the flesh is very high in vitamin A (4). There are small amounts of calcium, iron, thiamin, riboflavin, and niacin present in papaya (4). In addition, papaya contains a digestive enzyme, papain, a protease that is useful in tenderizing meat and other proteins (4). The papaya ringspot virus (PRSV) from the genus Potyvirus (5) is the major limiting factor for papaya production throughout tropical and subtropical areas (6). In fact, PRSV causes the most serious viral disease of papaya worldwide. The complete nucleotide sequences of severe Hawaii strain PRSV HA and a mosaic Taiwan strain PRSV YK have been determined $(7,8)$. Papaya has been genetically engineered to resist the PRSV. Two transgenic cultivars, Rainbow and SunUp (9,
10), which are hemizygous for the coat protein (CP) gene of PRSV, are resistant to PRSV in Hawaii and have been recently commercialized. Dr. Yeh's laboratory in Taiwan has also developed transgenic papaya with the coat protein gene of PRSV from Taiwan; some of these are resistant to PRSV strains from Taiwan, Thailand, and Hawaii (11).

Molecular biological methods enable studies of microbial diversity in environmental samples without cultivation. Molecular techniques based upon the analysis of rRNA genes are widely used for the assessment of bacterial community structure in soils $(12-16)$. The $16 \mathrm{~S}$ rRNA gene (rDNA) has been extensively applied to detect, identify, and measure microbial diversity from environmental samples. PCR amplification of the $16 \mathrm{~S}$ rRNA gene in combination with other molecular methods that generate fingerprints, such as amplified ribosomal DNA restriction analysis (ARDRA), terminal restriction fragment length polymorphism (T-RFLP), and denaturing gradient gel electrophoresis (DGGE), are now widely used successfully to compare bacterial populations in different soils (17-20).

The environmental risks of transgenic papaya are difficult to define because of the lack of scientific understanding about ecological interactions. It is unknown how the transgenic papaya will affect ecosystems or interact with the organisms present in the environment. There are almost no studies examining the interaction of transgenic papaya with other organisms. The methods involved in the risk assessment of GMOs have not been fully developed. Therefore, there is an urgent need for the 
Table 1. Primers Used in This Study

\begin{tabular}{lll}
\hline primer name & \multicolumn{1}{c}{ sequence $\left(5^{\prime}-3^{\prime}\right)$} & ref \\
\hline Msel adaptor & GAC GAT GAG TCC TGA G & 27 \\
Msel adaptor & TAC TCA GGA CTC AT & 27 \\
Msel primer & GAT GAG TCC TGA GTA CA & 27 \\
EcoRl adaptor & CTC GTA GAC TGC GTA CC & 27 \\
EcoRl adaptor & AAT TGG TAC GCA GTC & 27 \\
EcoRl primer & GTA GAC TGC GTA CCA ATT C & 27 \\
Pstl adaptor & CTC GTA GAC TGC GTA CAT GCA & 27 \\
Pstl adaptor & TGT ACG CAG TCT AC & 27 \\
Pstl primer & GAC TGC GTA CAT GCA & 27 \\
FAM-27 F & AGA GTT TGA TCC TGG CTC AG & 28 \\
FAM-1378 R & ACG GGC GGT GTG TAC A & 28 \\
341 F & CCT ACG GGA GGC AGC AG & 30 \\
534 R & ATT ACC GCG GCT GCT GG & 30 \\
GC clamp & CGC CCG CCG CGC GCG GCG GGC GGG GCG GGG G & 28 \\
\hline
\end{tabular}

development of scientific methods for the risk assessment of GMOs. In this study, we employed an approach in which AFLP, ARDRA, T-RFLP, and DGGE analyses were combined to assess microbial ecology in soils planted with transgenic papaya and nontransgenic papaya and in soils in which plants have not been grown.

\section{MATERIALS AND METHODS}

Materials. Soil Samples. Soil samples were collected from the Agricultural Research Institute (Tai-Chung, Taiwan) on August 9, 2004. Transgenic papaya plants there are $\sim 9$ years old. We collected the upper layer $(0-15 \mathrm{~cm})$ and lower layer $(15-30 \mathrm{~cm})$ of soil samples around the transgenic papaya planting area and the nontransgenic papaya planting area and from soils that have not been used to grow plants. Samples were sieved through $2 \mathrm{~mm}$ mesh sieve and stored at $4{ }^{\circ} \mathrm{C}$ before use.

Methods. Soil Properties. Soil pH value was measured in 1:1 (w/v) suspensions of soil and distilled water (21). The soil moisture was calculated from samples dried to constant weight at $110^{\circ} \mathrm{C}$ for $24 \mathrm{~h}$ and then cooled to room temperature. We calculated the moisture content from the decrease in soil weight (22). Total organic carbon content was measured using the Walkey-Black method (23). Soil nitrogen content was measured using the Kjeldahl method (24).

Microbial Populations. Total counts were cultured on nutrient agar plates; actinomycetes were obtained by culturing on glycerol yeast extract agar plates, and fungi were obtained by culturing on rose bengal medium at $25^{\circ} \mathrm{C}$ using the pour plate method. Microbial colonies were observed after $48 \mathrm{~h}$ of incubation with countable plates of the highest dilution being enumerated. Plates with $30-300$ colonies were selected for enumeration.

DNA Extraction and Purification. DNA was isolated using three methods: the method of Liu et al. (17), the method of Zhou et al. (25), and the method of Trevors and van Elsas (26). DNA purification was performed using the QIAquick Gel Extration Kit (Qiagen Co., Hilden, Germany). DNA was also extracted with the Ultraclean Soil DNA Extraction Kit from MoBio Laboratories (Solana Beach, CA).

AFLP Analysis. DNA (20 ng) was digested with $M s e_{\mathrm{W}}$ and $E c o R_{\mathrm{W}}$ (or $P s t_{\mathrm{W}}$ ), and the resulting fragments were ligated to double-stranded adapters (27). The digested and ligated DNA was then amplified by PCR using the $M s e_{\mathrm{W}}$ and $E c o R_{\mathrm{W}}\left(P s t_{\mathrm{W}}\right)$ 0/+0 primers in a final volume of $25 \mu \mathrm{L}$. Primers used in this study are shown in Table 1. PCR amplification was done with the following program: $72{ }^{\circ} \mathrm{C}$ for $2 \mathrm{~min}$; 20 cycles of denaturation at $94{ }^{\circ} \mathrm{C}$ for $30 \mathrm{~s}$, annealing at $56{ }^{\circ} \mathrm{C}$ for 30 $\mathrm{s}$, and extension at $72{ }^{\circ} \mathrm{C}$ for $2 \mathrm{~min}$. The $+0 /+0$ PCR product was analyzed by agarose gel electrophoresis. Four microliters of a 20 -fold dilution of the PCR product was used in subsequent selective amplifications with the $+1 /+0$ primer combination of $M_{s e} e_{\mathrm{W}}-\mathrm{C}$ and $E c o R_{\mathrm{W}}\left(P_{s} t_{\mathrm{W}}\right)$. Selective amplifications were performed in $25 \mu \mathrm{L}$ reactions using a cycling profile of $94{ }^{\circ} \mathrm{C}$ for $20 \mathrm{~s}, 66^{\circ} \mathrm{C}$ for $30 \mathrm{~s}$, and $72{ }^{\circ} \mathrm{C}$ for $2 \mathrm{~min}$ for 1 cycle and then lowering the annealing temperature by $1{ }^{\circ} \mathrm{C}$ for each cycle to $57{ }^{\circ} \mathrm{C}$ ( 9 cycles), followed by an additional 20 cycles at a $56{ }^{\circ} \mathrm{C}$ annealing temperature, and a single final extension at $60{ }^{\circ} \mathrm{C}$
Table 2. Properties of Soils

\begin{tabular}{|c|c|c|c|c|}
\hline soil type ${ }^{a}$ & $\begin{array}{c}\text { moisture } \\
\text { content (\%) }\end{array}$ & $\mathrm{pH}$ & $\begin{array}{c}\text { total } \\
\text { nitrogen (\%) }\end{array}$ & $\begin{array}{c}\text { total organic } \\
\text { carbon (\%) }\end{array}$ \\
\hline GU & $13.94 \pm 0.08$ & $5.89 \pm 0.21$ & $0.19 \pm 0.01$ & $8.56 \pm 0.09$ \\
\hline $\mathrm{GL}$ & $14.31 \pm 0.10$ & $6.16 \pm 0.0$ & $0.18 \pm 0$ & $8.02 \pm 0.13$ \\
\hline NU & $14.12 \pm 0.17$ & $6.37 \pm 0.12$ & $0.19 \pm 0.01$ & $8.24 \pm 0.18$ \\
\hline $\mathrm{NL}$ & $14.63 \pm 0.13$ & $6.58 \pm 0.08$ & $0.18 \pm 0.01$ & $7.76 \pm 0.21$ \\
\hline $\mathrm{CU}$ & $13.01 \pm 0.11$ & $5.93 \pm 0.04$ & $0.17 \pm 0.01$ & $7.97 \pm 0.19$ \\
\hline $\mathrm{CL}$ & $14.02 \pm 0.22$ & $6.18 \pm 0.05$ & $0.17 \pm 0.01$ & $7.29 \pm 0.08$ \\
\hline
\end{tabular}

${ }^{a} \mathrm{GU}$, upper layer soil around transgenic papaya planting area; GL, lower layer soil around transgenic papaya planting area; NU, upper layer soil around nontransgenic papaya planting area; NL, lower layer soil around nontransgenic papaya planting area; $\mathrm{CU}$, upper layer soil without planting papaya; $\mathrm{CL}$, lower layer soil without planting papaya.

Table 3. Microbial Populations in Varied Soils

\begin{tabular}{cccc}
\hline soil type & total count & $\begin{array}{c}\text { fungi } \\
\left(10^{6} \mathrm{CFU} / \mathrm{g}\right)\end{array}$ & $\begin{array}{c}\text { actinomycete } \\
\left(10^{4} \mathrm{CFU} / \mathrm{g}\right)\end{array}$ \\
\hline $\mathrm{GU}$ & $7.13 \pm 0.84$ & $7.96 \pm 0.64$ & $7.42 \pm 0.60$ \\
$\mathrm{GL}$ & $5.58 \pm 0.91$ & $5.17 \pm 0.75$ & $4.45 \pm 0.39$ \\
$\mathrm{NU}$ & $5.27 \pm 0.24$ & $5.45 \pm 0.34$ & $6.68 \pm 0.58$ \\
$\mathrm{NL}$ & $3.21 \pm 0.39$ & $2.43 \pm 0.16$ & $3.84 \pm 0.45$ \\
$\mathrm{CU}$ & $3.02 \pm 0.66$ & $2.25 \pm 0.45$ & $1.81 \pm 0.21$ \\
$\mathrm{CL}$ & $1.78 \pm 0.23$ & $1.20 \pm 0.09$ & $0.59 \pm 0.87$ \\
& & & \\
\hline
\end{tabular}

a Same as in Table 2.

Table 4. Quantity and Purity of DNA by Different Methods

\begin{tabular}{cccc}
\hline & $\begin{array}{c}\text { DNA yield } \\
\text { type of method }\end{array}$ & & \\
( $\mu$ g/g of dry soil) & $A_{260} / A_{280}$ & $A_{260} / A_{230}$ \\
\hline GU-method 1 & $14.78 \pm 0.83 \mathrm{~b}$ & $1.17 \pm 0.01 \mathrm{~b}$ & $0.44 \pm 0.03 \mathrm{~b}$ \\
GU-method 2 & $10.89 \pm 0.86 \mathrm{a}$ & $1.08 \pm 0.03 \mathrm{a}$ & $0.35 \pm 0.02 \mathrm{a}$ \\
GU-method 3 & $18.75 \pm 0.94 \mathrm{c}$ & $1.10 \pm 0.01 \mathrm{a}$ & $0.30 \pm 0.14 \mathrm{a}$ \\
GU-method 4 & $13.89 \pm 0.62 \mathrm{~b}$ & $1.42 \pm 0.13 \mathrm{c}$ & $0.86 \pm 0.09 \mathrm{c}$ \\
GL-method 1 & $13.38 \pm 0.57 \mathrm{~b}$ & $1.18 \pm 0.01 \mathrm{~b}$ & $0.45 \pm 0.03 \mathrm{~b}$ \\
GL-method 2 & $9.49 \pm 0.29 \mathrm{a}$ & $1.10 \pm 0.03 \mathrm{a}$ & $0.37 \pm 0.04 \mathrm{a}$ \\
GL-method 3 & $20.63 \pm 0.73 \mathrm{c}$ & $1.09 \pm 0.01 \mathrm{a}$ & $0.32 \pm 0.05 \mathrm{a}$ \\
GL-method 4 & $13.19 \pm 1.24 \mathrm{~b}$ & $1.35 \pm 0.07 \mathrm{c}$ & $0.96 \pm 0.05 \mathrm{c}$ \\
NU-method 1 & $13.89 \pm 0.29 \mathrm{~b}$ & $1.17 \pm 0.01 \mathrm{a}$ & $0.40 \pm 0.01 \mathrm{~b}$ \\
NU-method 2 & $9.27 \pm 0.37 \mathrm{a}$ & $1.11 \pm 0.04 \mathrm{a}$ & $0.33 \pm 0.02 \mathrm{a}$ \\
NU-method 3 & $18.40 \pm 0.94 \mathrm{c}$ & $1.15 \pm 0.07 \mathrm{a}$ & $0.30 \pm 0.01 \mathrm{a}$ \\
NU-method 4 & $13.20 \pm 1.21 \mathrm{~b}$ & $1.31 \pm 0.02 \mathrm{~b}$ & $0.92 \pm 0.09 \mathrm{c}$ \\
NL-method 1 & $14.86 \pm 0.93 \mathrm{~b}$ & $1.15 \pm 0.07 \mathrm{a}$ & $0.42 \pm 0.03 \mathrm{~b}$ \\
NL-method 2 & $9.15 \pm 0.57 \mathrm{a}$ & $1.09 \pm 0.05 \mathrm{a}$ & $0.34 \pm 0.08 \mathrm{a}$ \\
NL-method 3 & $20.70 \pm 0.57 \mathrm{c}$ & $1.13 \pm 0.05 \mathrm{a}$ & $0.32 \pm 0.01 \mathrm{a}$ \\
NL-method 4 & $15.56 \pm 1.02 \mathrm{~b}$ & $1.25 \pm 0.03 \mathrm{~b}$ & $0.91 \pm 0.07 \mathrm{c}$ \\
CU-method 1 & $15.19 \pm 0.37 \mathrm{~b}$ & $1.11 \pm 0.04 \mathrm{a}$ & $0.41 \pm 0.02 \mathrm{~b}$ \\
CU-method 2 & $9.73 \pm 0.57 \mathrm{a}$ & $1.07 \pm 0.03 \mathrm{a}$ & $0.32 \pm 0.01 \mathrm{a}$ \\
CU-method 3 & $16.19 \pm 0.81 \mathrm{~b}$ & $1.14 \pm 0.09 \mathrm{a}$ & $0.30 \pm 0.05 \mathrm{a}$ \\
CU-method 4 & $15.45 \pm 0.94 \mathrm{~b}$ & $1.35 \pm 0.02 \mathrm{~b}$ & $0.90 \pm 0.08 \mathrm{c}$ \\
CL-method 1 & $14.96 \pm 0.57 \mathrm{~b}$ & $1.13 \pm 0.01 \mathrm{a}$ & $0.38 \pm 0.02 \mathrm{~b}$ \\
CL-method 2 & $8.90 \pm 0.29 \mathrm{a}$ & $1.11 \pm 0.01 \mathrm{a}$ & $0.31 \pm 0.01 \mathrm{a}$ \\
CL-method 3 & $17.21 \pm 0.92 \mathrm{c}$ & $1.10 \pm 0.03 \mathrm{a}$ & $0.31 \pm 0.05 \mathrm{a}$ \\
CL-method 4 & $14.08 \pm 0.84 \mathrm{~b}$ & $1.20 \pm 0.03 \mathrm{~b}$ & $0.93 \pm 0.03 \mathrm{c}$
\end{tabular}

a Soil types are the same as in Table 2. Method 1, method of Liu et al. (17); method 2, method of Zhou et al. (25); method 3, method of Trevors and van Elsas (26); method 4, UltraClean Soil DNA Kit (Mo Bio Laboratories, Inc.).

for $30 \mathrm{~min}$. The $E c o R_{\mathrm{W}}$ (or $P s t_{\mathrm{W}}$ ) primer was labeled with the fluorescent dye 6-carboxyfluorescein (FAM). The fluorescently labeled AFLP products were analyzed by electrophoresis on an automatic sequence analyzer (ABI PRISM 3100 Genetic Analyzer, Applied Biosystems, Foster City, CA).

ARDRA Analysis. Bacterial 16S rDNA genes were amplified using the primer sets $27 \mathrm{~F}$ and $1378 \mathrm{R}$ (28). Primers used in this study are shown in Table 1. The PCR reaction mix for $50 \mu \mathrm{L}$ consisted of 2.5 
(a)

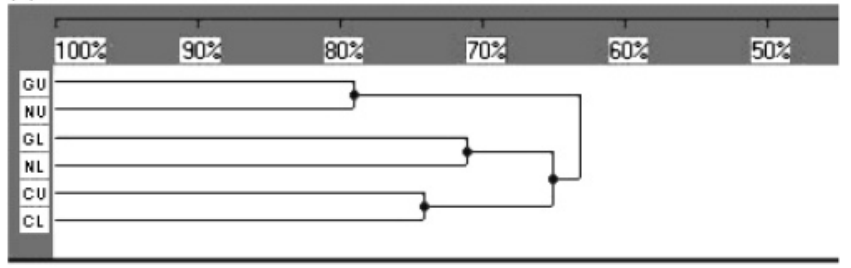

(b)

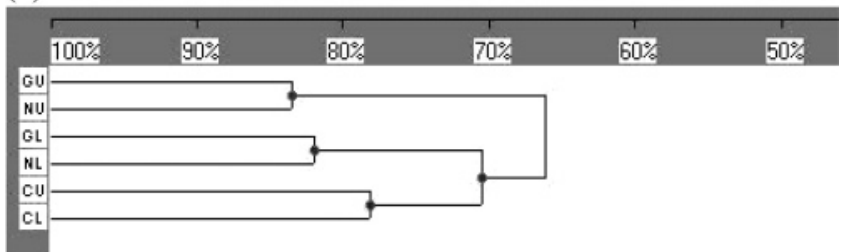

Figure 2. Dendrograms obtained by UPGMA analysis of AFLP profiles with (a) Msel-C/EcoRI primers and (b) Msel-C/Pstl primers from different soils. The soil kinds are the same as in Table 2. (a)

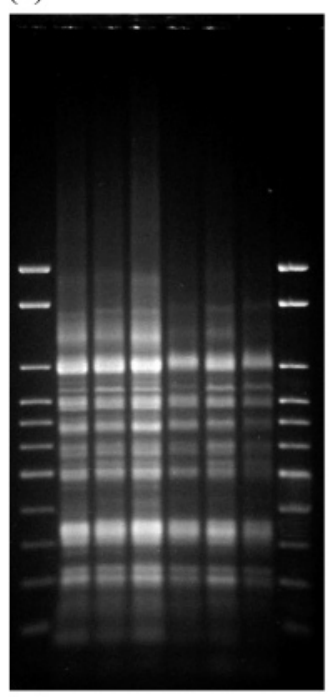

(c)

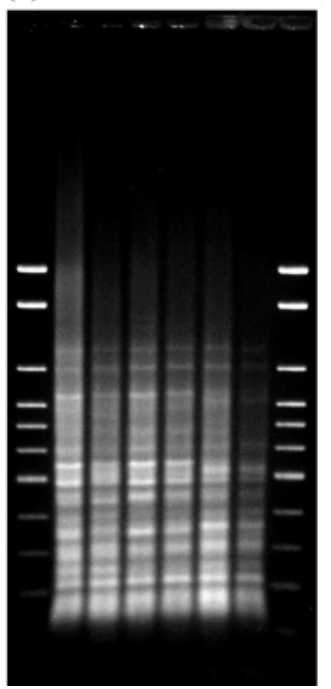

(b)

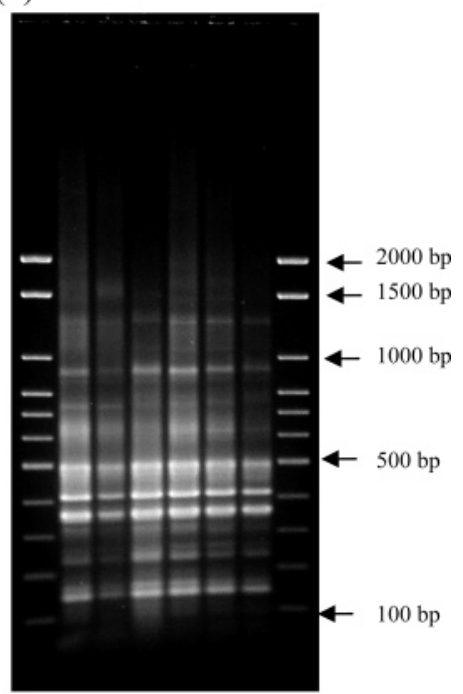

(d)

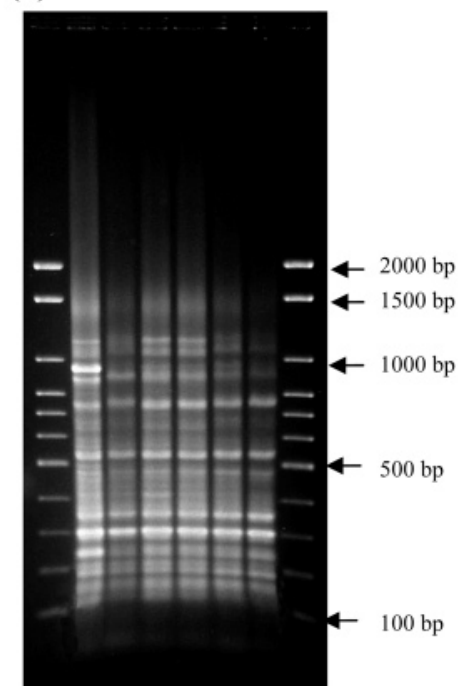

Figure 3. Comparison of ARDRA patterns of $16 \mathrm{~S}$ rDNA for bacteria from different soils digested with (a) Hinfl, (b) Rsal, (c) Mspl, and (d) Hhal: lanes 1 and 8, 100 bp marker; lane 2, upper layer soil around transgenic papaya planting area; lane 3 , lower layer soil around transgenic papaya planting area; lane 4, upper layer soil around nontransgenic papaya planting area; lane 5, lower layer soil around nontransgenic papaya planting area; lane 6, upper layer soil without planting papaya; lane 7, lower layer soil without planting papaya. 
(a)

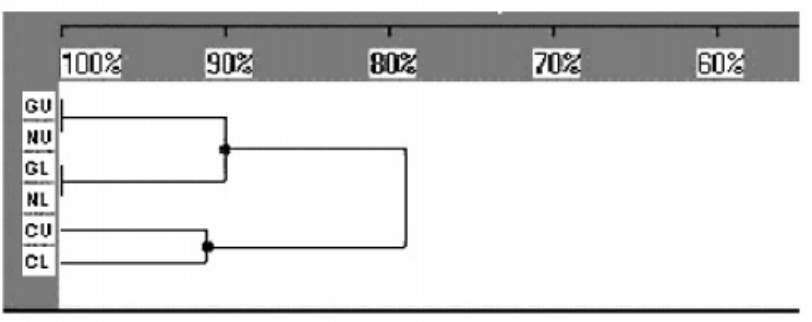

(c)

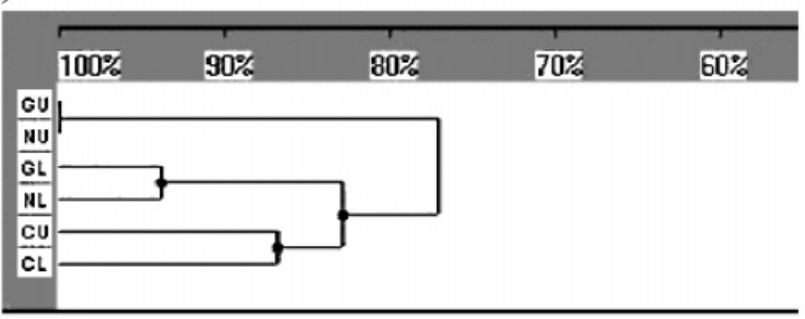

(b)

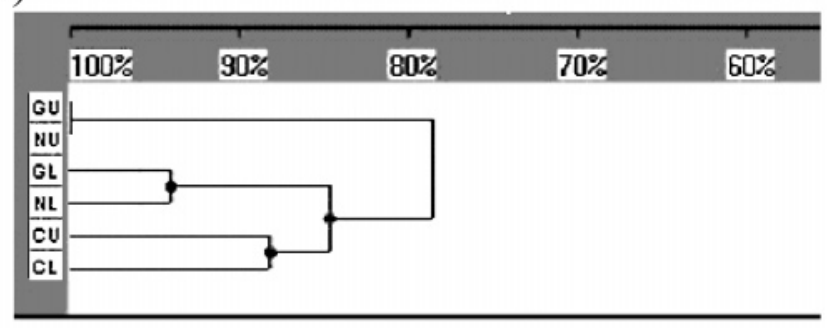

(d)

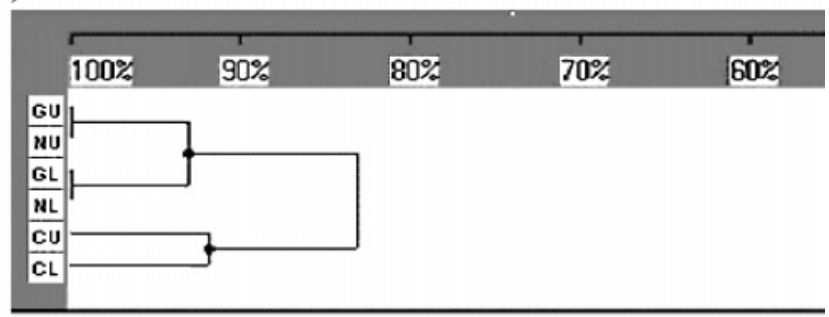

Figure 4. Dendrograms obtained by UPGMA analysis of ARDRA profiles digested with (a) Hinfl, (b) Rsal, (c) Mspl, and (d) Hhal from different soils. The soil kinds are the same as in Table 2.

units of Taq DNA polymerase, $200 \mu \mathrm{M}$ dNTP, $1 \times$ PCR buffer (Takara Biotechnology Co. Ltd., Shiga, Japan), 20 pmol of each primer (MDBio, Inc., Taipei, Taiwan), $1 \mu \mathrm{L}$ of a 5 -fold dilution of the DNA extract, and distilled water. PCR amplification was done with the following program: $94{ }^{\circ} \mathrm{C}$ for $8 \mathrm{~min} ; 30$ cycles of denaturation at $94{ }^{\circ} \mathrm{C}$ for 30 $\mathrm{s}$, annealing at $56{ }^{\circ} \mathrm{C}$ for $30 \mathrm{~s}$, and extension at $72{ }^{\circ} \mathrm{C}$ for $1 \mathrm{~min}$; and a single final extension at $72{ }^{\circ} \mathrm{C}$ for $10 \mathrm{~min}$.

PCR products were digested in a total volume of $30 \mu \mathrm{L}$ with 10 units of Hinf $\mathrm{W}_{\mathrm{W}}, H h a_{\mathrm{W}}, M s p_{\mathrm{W}}$, or Rsaw (New England BioLabs, Boston, MA) restriction enzymes for bacterial fingerprints. Electrophoreses were performed in $1.5 \%$ agarose (Amresco Inc., Solon, $\mathrm{OH}$ ) in $0.5 \times \mathrm{TBE}$ buffer at $100 \mathrm{~V}$ for $30 \mathrm{~min}$ and then evaluated to $200 \mathrm{~V}$ for $2 \mathrm{~h}$. Gels were stained by ethidium bromide and photographed under UV light.

T-RFLP Analysis. Bacterial 16S rDNA genes were amplified using the primer sets FAM-27 F and 1378 R. Primers used in this study are shown in Table 1. PCR reaction mix for $25 \mu \mathrm{L}$ consisted of 2.5 units of Taq DNA polymerase, $200 \mu \mathrm{M}$ dNTP, $1 \times$ PCR buffer (Takara Biotechnology Co. Ltd.), 20 pmol of each primer (MDBio, Inc.), $1 \mu \mathrm{L}$ of a 5-fold dilution of the DNA extract, and distilled water (29). PCR amplification was done with the same program as ARDRA.

PCR products of the correct size were confirmed by agarose gel electrophoresis and subsequently purified using QIAquick PCR purification kit (Qiagen Co.). The purified PCR products were digested with 10 units of $H i n f_{\mathrm{W}}, H h a_{\mathrm{W}}, M s p_{\mathrm{W}}$, or $R s a_{\mathrm{W}}$ (New England BioLabs) restriction enzymes for bacterial fingerprints. The fluorescently labeled terminal restriction fragments (T-RFs) were analyzed by electrophoresis on an automatic sequence analyzer (ABI Prism 3100 Genetic Analyzer, Applied Biosystems).

DGGE Analysis. Bacterial 16S rDNA genes were amplified using the primer sets $341 \mathrm{~F}$ and $534 \mathrm{R}(30)$. A GC clamp was attached to primer $341 \mathrm{~F}$ to prevent complete separation of the strands in the DGGE gel (28). Primers used in this study are shown in Table 1. All PCR reactions were carried out in a $50 \mu \mathrm{L}$ volume. PCR reaction mix was composed of 2.5 units of Taq DNA polymerase, $200 \mu \mathrm{M}$ dNTP, $1 \times$ PCR buffer (Takara Biotechnology Co. Ltd.), 20 pmol of each primer (MDBio, Inc.), $1 \mu \mathrm{L}$ of a 5-fold dilution of the DNA extract, and distilled water. PCR amplification was done with the following program: $95{ }^{\circ} \mathrm{C}$ for $5 \mathrm{~min} ; 30$ cycles of denaturation at $92{ }^{\circ} \mathrm{C}$ for 1 min, annealing at $55^{\circ} \mathrm{C}$ for $1 \mathrm{~min}$, and extension at $72{ }^{\circ} \mathrm{C}$ for $1 \mathrm{~min}$; and a single final extension at $72{ }^{\circ} \mathrm{C}$ for $10 \mathrm{~min}$.

PCR products were separated with DGGE through the DCode Universal Mutation Detection System (Bio-Rad Laboratories, Hercules, CA) using a $7 \%$ acrylamide gel with a $40-60 \%$ denaturing gradient (100\% denaturant solution was made of $7 \mathrm{M}$ urea and $40 \%$ deionized formamide). Gels were run at a constant temperature of $60^{\circ} \mathrm{C}$ for $6 \mathrm{~h}$ at $150 \mathrm{~V}$ in $1 \times \mathrm{TAE}$ buffer. After electrophoresis, the gels were stained using SYBR Green ${ }_{W}$ (Cambrex Bio Science Rocklane, Inc., Rocklane, ME) followed by visualization under UV light.

Statistical Analysis. Genetic similarity was calculated by dividing the number of bands that two samples have in common by the total number of different bands of those samples. On the basis of these values a matrix was made according to the unweighted pair-group arithmetic average (UPGMA) cluster analysis. This matrix was used to construct a dendrogram. Dendrograms were constructed by using PC-ORD 4 (MjM Software, Gleneden Beach, OR).

\section{RESULTS AND DISCUSSION}

Soil Properties. The properties of soils are shown in Table 2. Soils had moisture contents of $13.01-14.63 \%, \mathrm{pH}$ values of $5.89-6.58$, total nitrogen contents of $0.17-0.19 \%$, and total organic carbon contents of $7.29-8.56 \%$. The moisture contents, $\mathrm{pH}$ values, total nitrogen contents, and total organic carbon contents were not significantly different among soil kinds. The amount of total organic carbon content of upper layers was slightly higher than that of lower layers. The similar properties of the soils would decrease the external factor interference in the following research for the risk assessment of transgenic papaya.

Microbial Populations. Microbial populations from six different soils are shown in Table 3. The population of total count, fungi, and actinomycete from six different soils, respectively, ranged from $(1.78$ to 7.13$) \times 10^{6} \mathrm{CFU} / \mathrm{g}$, from $(1.20$ to $7.96) \times 10^{4} \mathrm{CFU} / \mathrm{g}$, and from (0.59 to 7.42$) \times 10^{4} \mathrm{CFU} / \mathrm{g}$, The microbial populations were highest in upper layer soils around transgenic papaya planting area and lowest in lower layer soils in which plants had not been grown. The microbial populations were all higher in upper layer soils.

DNA Extraction. The quantity and purity of DNA extracted by different methods are shown in Table 4 . We compared the efficiency of three kinds of traditional DNA extraction methods as well as an UltraClean Soil DNA Kit. The different extraction methods yielded DNA concentrations from six different soils ranging from 8.9 to $20.7 \mu \mathrm{g} / \mathrm{g}$ of dry soil. The $A_{260} / A_{280}$ ratio ranged from 1.07 to 1.42 , and the $A_{260} / A_{230}$ ratio was between 0.30 and 0.96 . The result showed that the highest amount of DNA was extracted following the method of Trevors and van Elsas, but the purity of DNA was better using the UltraClean Soil DNA Kit. No amplification was observed from the crude 


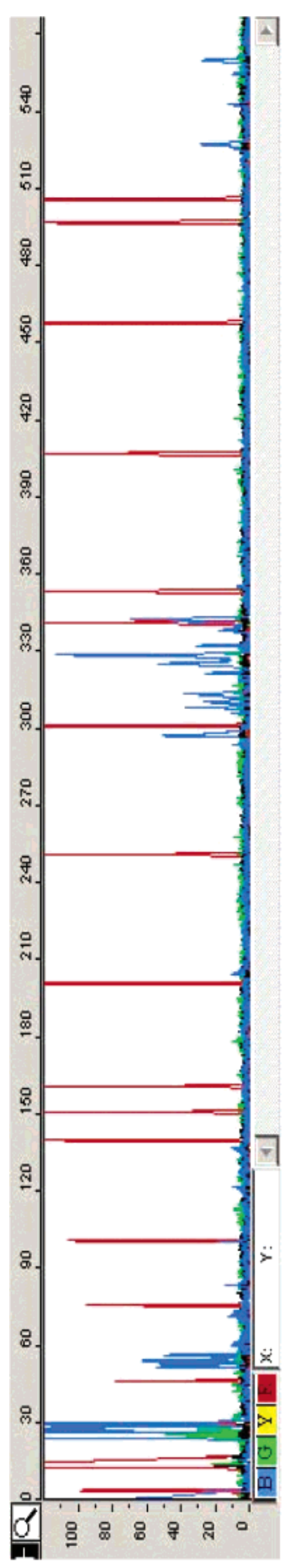

(્)

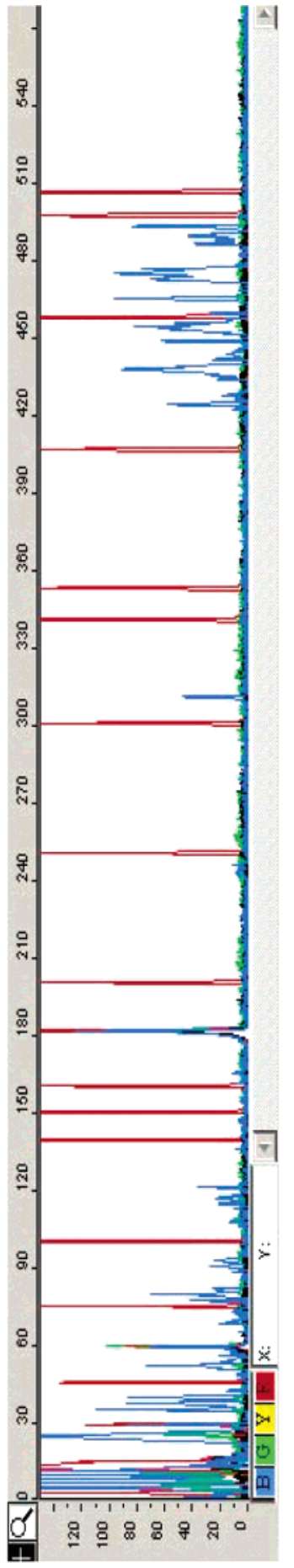

อ

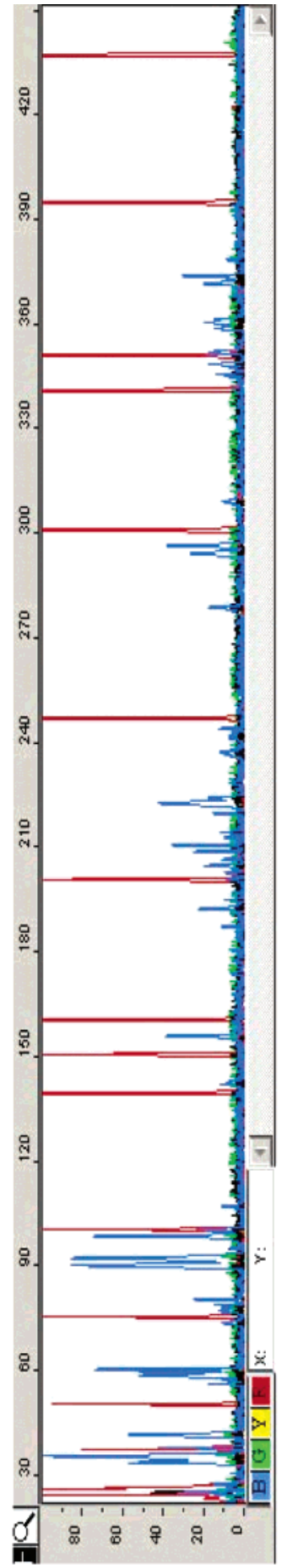

ชิ

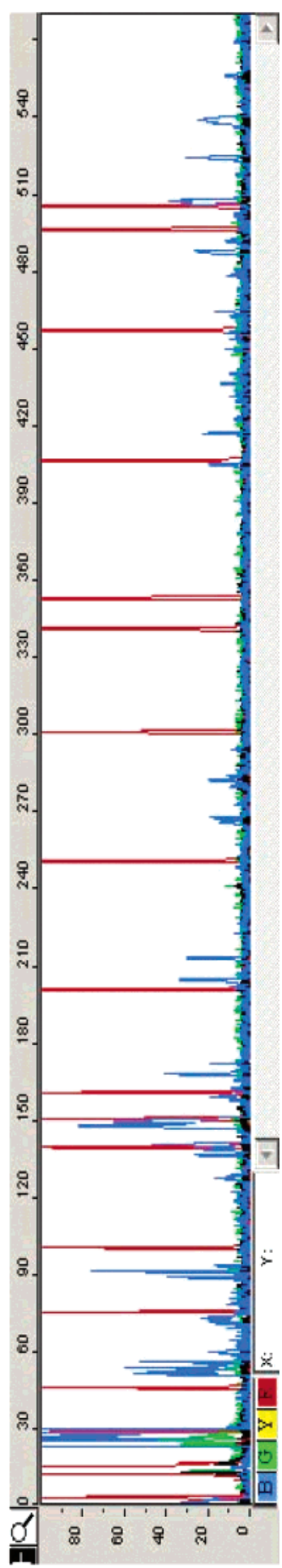

ซ્t

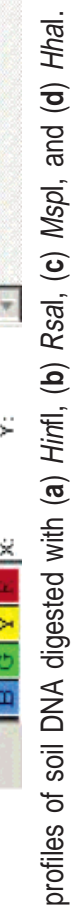

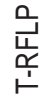


(a)

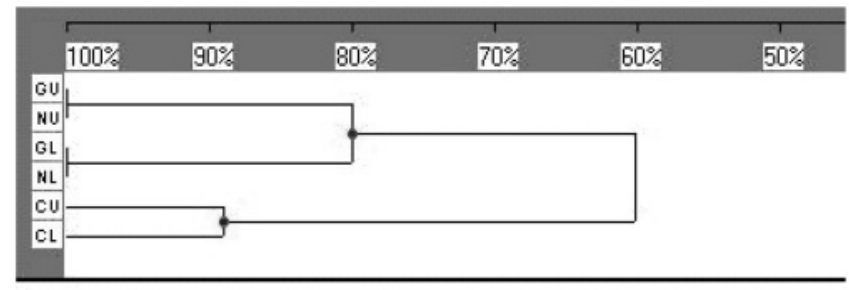

(c)

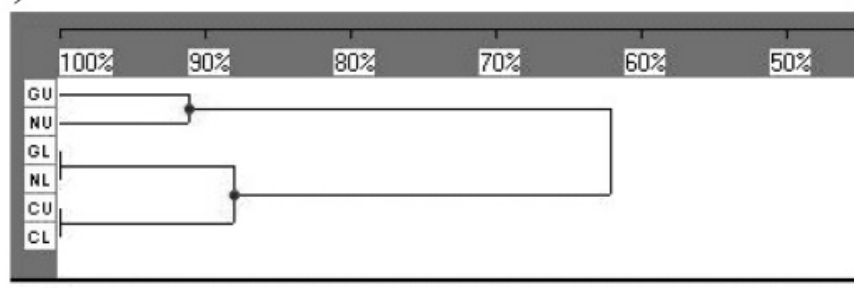

(b)

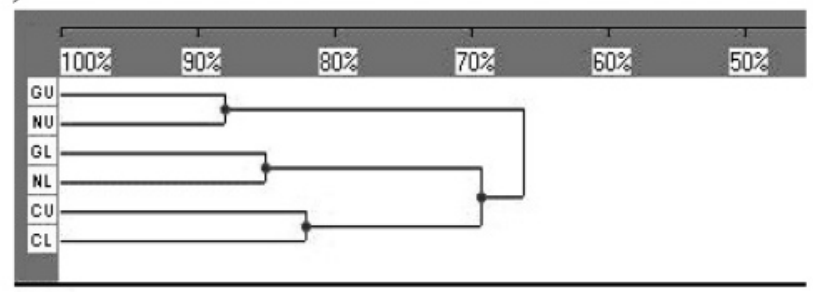

(d)

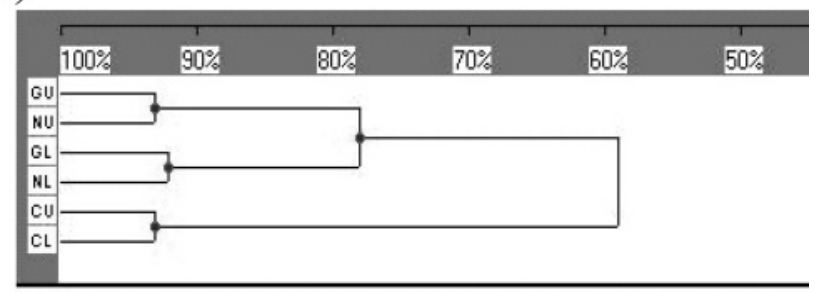

Figure 6. Dendrograms obtained by UPGMA analysis of T-RFLP profiles digested with (a) Hinfl, (b) Rsal, (c) Mspl, and (d) Hhal from different soils. The soil kinds are the same as in Table 2.

extracts of the six soils tested by using traditional DNA extraction methods. According to the previous studies, impurities such as humic acid in the extracts may affect DNA hybridization efficiency (31) and enzyme digestion (32) and inhibit Tag polymerase activity $(33,34)$, and DNA extracted with traditional methods should be purified to remove humic acid in order to proceed with PCR. The removal of humic acid is difficult, but it is necessary to obtain DNA to be used in PCR. We used the DNA extracted with the UltraClean Soil DNA Kit in the following analysis.

AFLP Analysis. The fluorescent AFLP analysis generated fragments of between 60 and 500 bp for each sample by using just one set of +1 primers (Figure 1). AFLP data are generated as peak height and peak locations. Fluorescence peak height is influenced by the amount of product in the peak. Each peak represents one or more DNA fragments, and the location or relative migration of the fragment through the gel is directly related to the DNA fragment size. The AFLP fingerprints were used to produce dendrograms from the similarity matrix of Jaccard coefficients and the UPGMA methods. The dendrogram based on the AFLP data is shown in Figure 2. The result of AFLP analysis showed GU and NU had the highest similarity, GL and NL clustered together, and $\mathrm{CU}$ and $\mathrm{CL}$ clustered together regardless of whether $M s e_{\mathrm{W}}-\mathrm{C} / E c o R_{\mathrm{W}}$ or $M s e_{\mathrm{W}}-\mathrm{C} / P s t_{\mathrm{W}}$ primers were used. The result indicated that the similarity of soil microorganisms of upper layer soils around transgenic papaya planting area and around nontransgenic papaya planting area. A similar result was observed in lower layer soils. Thus, planting transgenic papayas does have a limit impact on soil microorganisms according to AFLP analysis result.

ARDRA Analysis. The restriction enzymes HinfI, RsaI, MspI, and HhaI were used to digest the PCR products. The PCR fragment size of amplified 16S rRNA gene of bacteria using the primer pair for bacteria was $\sim 1.5 \mathrm{~kb}$. The $16 \mathrm{~S}$ rDNA fingerprints (Figure 3) did not display large differences among soil samples whatever the enzyme used here and showed that the genetic structure of the bacteria community was homogeneous among samples. Whole community ARDRA patterns digested by HinfI, RsaI, MspI, and HhaI were used to calculate the genetic similarity of the different soil microbial communities. Genetic similarity was calculated by pairwise comparison of bands of ARDRA patterns of different soils (Figure 4). Cluster analysis showed GU and NU had $100 \%$ similarity whatever the enzyme used, GL and NL had $>90 \%$ similarity, and CU and CL had $>87 \%$ similarity. The result revealed that planting transgenic papayas has little influence on soil microorganisms.

T-RFLP Analysis. The T-RFLP method is a derivative of ARDRA and makes use of a fluorescence-labeled primer for PCR (17). A prerequisite for a meaningful comparative analysis of T-RFLP patterns generated from different environmental samples is high accuracy in the determination of both size and signal intensity of individual T-RFs. The accuracy of the automated size determination has been demonstrated $(35,36)$. The fluorescent T-RFLP analysis generated T-RFs of between 30 and $560 \mathrm{bp}$ from samples using different restriction enzymes (Figure 5). Figure 6 shows the UPGMA-based dendrograms obtained from T-RFLP profile analysis of the bacteria using the $27 \mathrm{~F} / 1378 \mathrm{R}$ primer set. Cluster analysis showed GU and NU had $>88 \%$ similarity, GL and NL had $>86 \%$ similarity, and CU and CL had $>82 \%$ similarity whatever the enzyme used. The result was similar to that in ARDRA analysis. A similar result has been reported in a previous study (37), which assessed microbial ecology in soil planted with transgenic Bt corn by T-RFLP and indicated the release of Bt corn poses little threat to the ecology of the soil microbial community. It is the same result in this study.

DGGE Analysis. DGGE provides the potential for analysis of sequence diversity of complex natural microbial populations (30). DGGE fingerprints of the natural samples (Figure 7) revealed the presence of a complex community of bacteria. The patterns obtained from each field treatment contained relatively high numbers of clear bands at different positions having different intensities. DGGE analysis of PCR products amplified with the $341 \mathrm{~F} / 534 \mathrm{R}$ primer set showed a qualitatively similar banding pattern irrespective of different soils. The UPGMAbased dendrogram (Figure 8) describes the similarities between the DGGE patterns of the different soils in GU and NU clusters with similarity of $\sim 86 \%$. The patterns obtained from GL and NL formed one separate cluster with $\sim 83 \%$ internal similarity, and the patterns obtained from CU and CL formed one separate cluster with $\sim 71 \%$ similarity. The result was similar to that in AFLP, ARDRA, and T-RFLP, indicating that the similarity of soil microorganisms of upper layer soils around transgenic papaya planting area and around nontransgenic papaya planting 


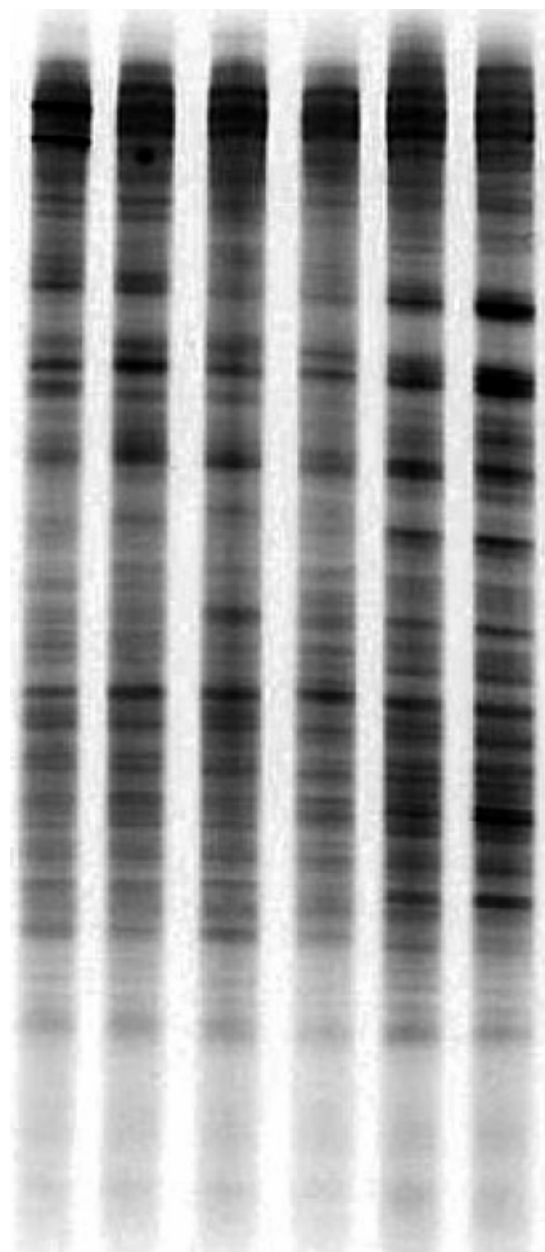

Figure 7. Comparison of microbial diversity by DGGE profiles using primer pair 338F-GC/534R: lane 1, upper layer soil around transgenic papaya planting area; lane 2, lower layer soil around transgenic papaya planting area; lane3, upper layer soil around nontransgenic papaya planting area; lane 4, lower layer soil around nontransgenic papaya planting area; lane 5 , upper layer soil without planting papaya; lane 6 , lower layer soil without planting papaya.

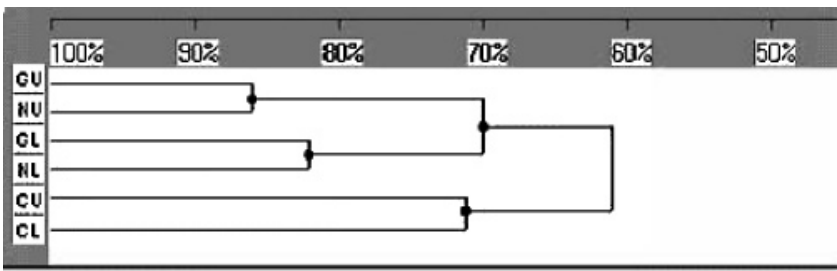

Figure 8. Dendrogram obtained by UPGMA analysis of DGGE profiles from different soils. The soil kinds are the same as in Table 2.

area. A similar result was observed in lower layer soils. Thus, planting transgenic papayas limits the impact on soil microorganisms.

PCR amplification of rRNA genes from environmental DNA samples, combined with fingerprinting techniques, such as ARDRA, T-RFLP, and DGGE, provides detailed information about the species composition of whole communities (38). In this study, we combined AFLP, ARDRA, T-RFLP, and DGGE analyses to assess microbial ecology in soils. The result of analysis using the four molecular methods indicated that the similarity of soil microorganisms of upper layer soils around transgenic papaya planting area and around nontransgenic papaya planting area was $>80 \%$. A similar result was observed in lower layer soils. Thus, planting transgenic papayas does limit impact on soil microorganisms. The difference between conventional and transgenic papayas is that the coat protein can be found in only transgenic papayas. The results show that the coat protein in transgenic papayas may have little influence on soil microorganisms, possibly because its quantity is very low or has not been secreted. The extrapolation would need further experimentation to be confirmed.

\section{LITERATURE CITED}

(1) James, C. Global status of commercialized biotech/GM crops: 2004. ISAAA Briefs 2004, No. 32

(2) Chiter, A.; Forbes, J. M.; Blair, G. E. DNA stability in plant tissues: implications for the possible transfer of genes from genetically modified food. FEBS Lett. 2000, 481, 164-168.

(3) Bloemberg, G. V.; Lugtenberg, B. J. J. Molecular basis of plant growth promotion and biocontrol by rhizobacteria. Curr. Opin. Plant Biol. 2001, 4, 343-350.

(4) Manshardt, R. M. Papaya. In Biotechnology of Perennial Fruit Crops; Hammerschlag, F. A., Litz, R. E., Eds.; CAB International: Wallingford, U.K., 1999; Vol. 21, pp 489-511.

(5) Ward, C. W.; Shukla, D. D. Taxonomy of potyviruses: current problems and some solutions. Intervirology 1991, 32, 269-296.

(6) Purcifull, D. E.; Edwardson, J. R.; Hiebert, E.; Gonsalves, D. Papaya ringspot virus. CMI/AAB Descriptions of Plant Viruses; 1984; p 292.

(7) Wang, C. H. Comparison of the complete nucleotide sequences of Taiwan and Hawaii strains of papaya ringspot virus. Ph.D thesis, Department of Plant Pathology, National Chung-Hsing University, Taichung, Taiwan 1993; p 152.

(8) Yeh, S. D.; Jan, F. J.; Chiang, C. H.; Doong, T. J.; Chen, M. C.; Chung, P. H.; Bau, H. J. Complete nucleotide sequence and genetic organization of papaya ringspot virus RNA. J. Gen. Virol. 1992, 73, 2531-2541

(9) Bateson, M.; Henderson, J.; Chaleeprom, W.; Gibbs, A.; Dale, J. Papaya ringspot potyvirus: isolate variability and origin of PRSV type P (Australia). J. Gen. Virol. 1994, 75, 3547-3453.

(10) Wang, C. H.; Bau, H. J.; Yeh, S. D. Comparison of the nuclear inclusion protein and coat protein genes of five papaya ringspot virus strains distinct in geographic origin and pathogenicity. Phytopathology 1994, 84, 1205-1210.

(11) Yeh, S. D.; Cheng, Y. H.; Bau, H. J.; Yu, T. A.; Yang, J. S. Coat-protein transgenic papaya immune or highly resistant to different strains of papaya ringspot potyvirus. Phytopathology 1997, 87, S107 (Abstr.).

(12) Felske, A.; Akkermans, A. D. L. Spatial homogeneity of abundant bacterial 16S rRNA molecules in grassland soils. Microb. Ecol. 1998, 36, 31-36.

(13) Smit, E.; Leefang, P.; Glandorf, B.; van Elsas, J. D.; Wernars, $\mathrm{K}$. Analysis of fungal diversity in the wheat rhizosphere by sequencing of cloned PCR-amplified genes encoding 18S rRNA and temperature gradient gel electrophoresis. Appl. Environ. Microbiol. 1999, 65, 2614-2621.

(14) Borneman, J.; Hartin, R. J. PCR primers that amplify fungal rRNA genes from environmental samples. Appl. Environ. Microbiol. 2000, 66, 4356-4360.

(15) Bruce, K. D.; Hughes, M. R. Terminal restriction fragment length polymorphism monitoring of genes amplified directly from bacterial communities in soils and sediments. Mol. Biotechnol. 2000, 16, 261-269.

(16) Ranjard, L.; Poly, F.; Nazaret, S. Monitoring complex bacterial communities using culture-independent molecular techniques: application to soil environment. Res. Microbiol. 2000, 151, 167177.

(17) Liu, W. T.; Marsh, T. L.; Cheng, H.; Forney, L. J. Characterization of microbial diversity by determining terminal restriction fragment length polymorphisms of genes encoding $16 \mathrm{~S}$ rRNA. Appl. Environ. Microbiol. 1997, 63, 4516-4522.

(18) Ovreas, L.; Torsvik, V. Microbial diversity and community structure in two di!erent agricultural soil communities. Microb. Ecol. 1998, 36, 303-315. 
(19) Muyzer, G. DGGE/TGGE a method for identifying genes from natural ecosystems. Curr. Opin. Microbiol. 1999, 2, 317-322.

(20) Ranjard, L.; Poly, F.; Lata, J. C.; Mougel, C.; Thioulouse, J.; Nazaret, S. Characterization of bacterial and fungal soil communities by automated ribosomal intergenic spacer analysis fingerprints: biological and methodological variability. Appl. Environ. Microbiol. 2001, 67, 4479-4487.

(21) Mclean, E. O. Soil pH and lime requirement. In Methods of Soil Analysis, Part 2. Chemical and Microbiological Properties, 2nd ed.; Page, A. L., Ed.; Academic Press: New York, 1982; pp 199-224.

(22) Gardner, W. H. Water content. In Methods of Soil Analysis, Part 1. Physical and Mineralogical Methods, 2nd ed.; Klute, A., Ed.; Agronomy Monograph 9; ASA and SSSA: Madison, WI, 1986; pp 493-544.

(23) Rabenhorst, M. C. Determination of organic carbon in calcareous soil using dry combustion. Soil Sci. Soc. Am. J. 1988, 52, 915969.

(24) Bremmer, J. M.; Mulvaney, C. S. Salicylic acid-thiosulfate modification on Kjeldahl method to include nitrate and nitrite. In Methods of Soil Analysis, Part 2. Chemical and Microbiological Properties, 2nd ed.; Page, A. L., Ed.; Academic Press: New York, 1982; pp 621-622.

(25) Zhou, J.; Bruns, M. A.; Tiedje, J. M. DNA recovery from soils of diverse composition. Appl. Environ. Microbiol. 1996, 62, 316-322.

(26) Trevors, J. T.; van Elsas, J. D. Nucleic Acid in the Environment: Methods and Applications; Springer Press: Berlin, Germany, 1995; p 52.

(27) Vos, P.; Hogers, R.; Bleeker, M.; Reijans, M.; van de Lee, T.; Hornes, M.; Frijters, A.; Pot, F.; Peleman, J.; Kuiper, M.; Zabeau, M. AFLP: a new technique for DNA fingerprinting. Nucleic Acids Res. 1995, 23, 4407-4414.

(28) Heuer, H.; Krsek, M.; Baker, P.; Smalla, K.; Wellington, E. M. Analysis of actinomycete communities by specific amplification of genes encoding 16S rRNA and gel-electrophoretic separation in denaturing gradients. Appl. Environ. Microbiol. 1997, 63, $3233-3241$

(29) Christopher, B. B.; Eldor, A. P. Eubacterial community structure and population size within the soil light fraction, rhizosphere, and heavy fraction of several agricultural systems. Soil Boil. Biochem. 2003, 35, 1245-1255.
(30) Muyzer, G.; De Waal, E. D.; Uitterlinden, A. G. Profiling of complex microbial populations by denaturing gradient gel electrophoresis analysis of Polymerase Chain Reaction-amplified genes coding for 16S rRNA. Appl. Environ. Microbiol. 1993, 59, 695-700.

(31) Stefan, R. J.; Goksoyr, J.; Bej, A. K.; Atlas, R. M. Recovery of DNA from soils and sediments. Appl. Environ. Microbiol. 1998, 45, 137-161.

(32) Tebbe, C. C.; Vahjen, W. Interference of humic acid and DNA extracted directly from soil in detection and transformation of recombinant DNA from bacteria and a yeast. Appl. Environ. Microbiol. 1993, 59, 2655-2657.

(33) Torsvik, V. Isolation of bacterial DNA from soil. Soil Biol. Biochem. 1980, 12, 15-21.

(34) Tsai, Y. L.; Olson, B. M. Rapid method for separation of bacterial DNA from humic substances in sediments for polymerase chain reaction. Appl. Environ. Microbiol. 1992, 57, 1071-1074.

(35) Mayrand, P. E.; Corcoran, K. P.; Ziegle, J. S.; Robertson, J. M.; Hoff, L. B.; Kronick, M. N. The use of fluorescence detection and internal lane standards to size PCR products automatically. Appl. Theor. Electrophor. 1992, 3, 1-11.

(36) Ziegle, J. S.; Su, Y.; Corcoran, K. P.; Nie, L.; Mayrand, P. E.; Hoff, L. B.; McBride, L. J.; Kronick, M. M.; Diehl, S. R. Application of automated DNA sizing technology for genotyping microsatellite loci. Genomics 1992, 14, 1026-1031.

(37) Devare, M. H.; Jones, C. M.; Thies, J. E. Effect of Cry3Bb transgenic corn and tefluthrin on the soil microbial community: biomass, activity and diversity. J. Environ. Qual. 2004, 33, 837843.

(38) Torsvik, V.; Ovreas, L. Microbial diversity and function in soil: from genes to ecosystems. Curr. Opin. Microbiol. 2002, 5, 240245 .

Received for review August 14, 2005. Revised manuscript received November 1, 2005. Accepted November 3, 2005.

JF051999I 